Article

\title{
Tree Species Diversity and Socioeconomic Perspectives of the Urban (Food) Forest of Accra, Ghana
}

\author{
Bertrand F. Nero ${ }^{1,2, *}$, Nana Afranaa Kwapong ${ }^{1,3}$, Raymond Jatta ${ }^{1}$ and Oluwole Fatunbi ${ }^{1}$ \\ 1 Forum for Agricultural Research in Africa (FARA), 12 Anmeda Street, PMB CT 173, Accra 233, Ghana; \\ nkwapong@faraafrica.org (N.A.K.); rjatta@faraafrica.org (R.J.); ofatunbi@faraafrica.org (O.F.) \\ 2 Department of Forest Resources Technology, Kwame Nkrumah University of Science and Technology, PMB, \\ University Post Office, Kumasi 233, Ghana \\ 3 Department of Agricultural Extension, University of Ghana, P.O. Box LG 68, Legon, GA-492-3175 Accra, Ghana \\ * Correspondence: bfnero@knust.edu.gh or bnero@faraafrica.org
}

Received: 30 June 2018; Accepted: 21 September 2018; Published: 25 September 2018

\begin{abstract}
Urban and peri-urban forestry has emerged as a complementary measure to contribute towards eliminating urban hunger and improved nutritional security. However, there is scanty knowledge about the composition, diversity, and socioeconomic contributions of urban food trees in African cities. This paper examines the diversity and composition of the urban forest and food trees of Accra and sheds light on perceptions of urbanites regarding food tree cultivation and availability in the city. Using a mixed methods approach, 105 respondents in six neighborhoods of Accra were interviewed while over 200 plots (100- $\mathrm{m}^{2}$ each) were surveyed across five land use types. Twenty-two out of the 70 woody species in Accra have edible parts (leaves, fruits, flowers, etc.). The food-tree abundance in the city is about half of the total number of trees enumerated. The species richness and abundance of the food trees and all trees in the city were significantly different among land use types $(p<0.0001)$ and neighborhood types $(p<0.0001)$. The diversity of food-bearing tree species was much higher in the poorer neighborhoods than in the wealthier neighborhoods. Respondents in wealthier neighborhoods indicated that tree and food-tree cover of the city was generally low and showed greater interest in cultivating food (fruit) trees and expanding urban forest cover than poorer neighborhoods. These findings demonstrate the need for urban food policy reforms that integrate urban-grown tree foods in the urban food system/culture.
\end{abstract}

Keywords: mixed methods; richness; edible; food bearing; neighborhoods

\section{Introduction}

Malnutrition, poverty and food insecurity, once thought to be characteristic of rural areas, have become prevalent in cities of rapidly urbanizing regions such as Africa [1]. About $40 \%$ of Africa's urban population lives below the poverty line (US\$2.0 per day), while an estimated $72 \%$ lives in slums [2,3]. Furthermore, four out of every five urban households in Africa are food insecure with the urban poor being the most severely affected [1] and about one-fifth of them spend up to $70 \%$ of their income on food [4]. Incorporating tree-food cultivation and conservation in the urban landscape and within human settlements could enhance food security and complement traditional food security strategies including agriculture [5,6]. However, data about the contribution of trees/forests to food and nutritional security especially in urban areas are lacking or at best scanty and fragmentary.

Urbanization has massive implications for food security in cities of many developing countries. It is projected to cause about $3 \%$ and $9 \%$ loss of prime agricultural lands and food production, respectively, in Africa by 2030 [7]. It will also trigger declines in the agricultural labor force and 
further depletion of urban green spaces [8,9]. These transformations have inspired donor-aided importation of cereals to sustain the burgeoning urban populations in many West African countries [10]. Consequently, there is an evolution of the urban food culture towards increased consumption of cheap fast foods [11,12], which together with the traditional staples of cereals, roots, and tubers is gradually resulting in increased cases of malnutrition, obesity, and stunting [12,13]. Food and nutritional insecurity is more severe in some urban areas than in rural areas [13]. Addressing these challenges requires locally relevant knowledge, supportive policies, and optimal physical and social environments [14].

One target of the sustainable development goals is to eliminate hunger and all its forms by 2030 . Similarly, the African Union Summit at Malabo, Equatorial Guinea, in 2014 adopted the declaration to end hunger by doubling agricultural productivity levels and eliminating child malnutrition by $2025[12,15]$. However, there is growing evidence that agricultural strategies alone fall short of eliminating hunger, result in unbalanced diets that lack nutritional diversity, enhance exposure of the most vulnerable groups to volatile food prices, and fail to recognize the long-term consequences of intensified agricultural systems [16,17]. In parallel, there is growing evidence that forest- and tree-based systems can play significant roles in complementing agricultural production in the food security discourse. Food security also includes nutrition security and access to food, which ensures adequate macro- and micronutrient intake without excessive intake of calories [17].

Forest directly provides a diversity of healthy foods rich in micronutrients and fiber but low in sodium and refined fats and sugar, i.e., foods that are culturally valued and integral to the local food systems and food sovereignty, and that fill seasonal or cyclical food gaps and serve as safety nets or buffers in times of critical food shortage [16-18]. Forests within cities directly supply fruits, vegetables, seeds, oils, and nuts, which provide essential nutrients including vitamins and minerals [18]. Urban forests indirectly supply food through urban apiculture, silvopastoral practices (e.g., Piper nigrum), taungya systems, and snail and grasscutter farming [18]. Urban agroforestry is a promising option that could be integrated into a broader concept of urban food forestry [18-20] to sustain food security and environmental wellbeing. The inclusion of trees in food and nutrition security is fairly recent [5]. However, few studies have characterized urban food tree species diversity and composition within cities in West Africa [21,22] despite evidence that children who live in areas with high forest/tree cover enjoy greater dietary diversity and more nutritious foods [23].

Ghana, like most countries in sub-Saharan Africa (SSA), is undergoing rapid urbanization with an urban population (which now stands at $54 \%$ ) projected to increase to $75 \%$ by 2050 [24,25]. Increases in human population lead to urban sprawl, which results in loss of agricultural and natural vegetation cover. Besides, food insecurity in Ghana is most prevalent in urban areas [26] where urban diets consist more of animal, sugary, and fatty foods and less of fruits and vegetables [27,28]. However, to date there is no known study on perceptions of the urbanites or composition and diversity of urban food-tree species across the variety of land uses and neighborhood types in this country. Additionally, about two out of every three school-age children in urban Ghana experience at least one nutritional deficit and are either stunted, underweight or anaemic with calcium intake being very low [28].

\section{Materials and Methods}

\subsection{Study Area}

The study was conducted in Accra $\left(5^{\circ} 35^{\prime \prime} \mathrm{N}, 0^{\circ} 60^{\prime \prime} \mathrm{W}\right)$, Ghana. Accra is the capital of Ghana and is located on the Gulf of Guinea. It has a total land area of more than $250 \mathrm{~km}^{2}$ and a population of about 2.27 million [25]. The greater Accra Metropolitan Area (AMA) is estimated to have a population of 4 million. It is a cosmopolitan city that is socioeconomically stratified based on environmental quality [29]. Neighborhood socioeconomic conditions have also been shown to correlate strongly with vegetation cover with poorer neighborhoods being less green and wealthier neighborhoods being more green [30]. The six study neighborhoods lie on a line from the coast towards the northern boundaries 
of the AMA, i.e., Jamestown/Ushertown (JT), Asylum Down (AD), Kanda (KN), Nima (NM), Roman Ridge (RR), and East Legon (EL). JT is one of the oldest neighborhoods of Accra and lies between the coast and Accra business center; AD and NM are located approximately $3 \mathrm{~km}$ inland separated by the Ring Road central. The Kanda highway separates NM and KN. RR and EL are approximately 5 and $10 \mathrm{~km}$ inland and west and north of the Accra International Airport, respectively.

Accra is in the equatorial climatic region, one of the driest regions in Ghana. Its mean annual precipitation and temperature are about $809 \mathrm{~mm}$ and $26.6^{\circ} \mathrm{C}$, respectively [31]. Humidity is generally high (65\%-95\%).

Savannah grasslands and thickets were the dominant vegetation type in the Accra plains prior to recent urbanization. Originally, a dry semi-deciduous forest of the "south-east outlier type" was the natural vegetation cover of the Accra plains. Over several millennia, human activities have successfully transformed this dry forest into the present savannah type [32]. The dry forest was a multistory closed canopy forest composed of several woody tree and liana species such as Millettia thonningii, Diospyros spp., Ceiba spp., etc. With such high tree diversity, the dry forest more likely supported more food-bearing trees than the savannah. On the other hand, the open savannah is easier to exploit for farming and grazing.

The study employed a mixed-methods approach in gathering the data. Mixed methods is a research approach where researchers collect, analyze, and integrate quantitative and qualitative data in a single study or a sustained long-term project [33]. The approach in this study is based on the fact that the research questions are best addressed by complementing both quantitative and qualitative data. The quantitative data were collected through vegetation inventory, while semi-structured questionnaires were used to collect qualitative data. Gathering both qualitative and quantitative data aided the generation of multiple perspectives about the contribution of urban forests to urban food security in Accra.

\subsection{Vegetation Sampling Design}

The plots were located in Accra in a stratified random sampling design in 2017 as part of the urban biomass study in Ghana $[9,10]$. Stratification was based on the relative homogeneity of the physiognomic units of land uses. Five land uses, i.e., home gardens (HG), cemeteries/sacred grooves (C), public parks (PP), institutional compounds (IC), and streets (S) were identified with the aid of land use maps and Google Earth images.

A total of 200 relevés and 5 streets were surveyed. Sample areas were $100 \mathrm{~m}^{2}$ in the parks and cemeteries, while entire areas of the institutional compounds and home gardens were surveyed. The trees and shrubs within each relevé were counted by species and the number recorded. All trees were identified to the species level with the aid of tree identification experts and published tree identification guides such as those by Hawthorne and Gyakari [34] and Oteng-Amoako [35]. Samples of unidentified tree species were collected and processed following standard taxonomic procedures and subsequently forwarded to the University of Ghana and Forestry Research Institute of Ghana Herbaria. The selection of home gardens followed the systematic approach described below under the socioeconomic survey section.

\subsection{Socioeconomic Survey}

Data on the urbanites' perceptions and use of urban forest trees for food and their interest in cultivating and promoting urban food forestry were collected by means of semi-structured and structured interviews and observations. Respondents were drawn from three classes of neighborhoods, i.e., high income, middle income, and low income, and interviewed between September and November 2017. JT and NM were selected in the low-income category, KN and AD in the middle-income neighborhood and EL and RR in the high-income neighborhood [29,36,37]. Within each neighborhood, a systematic sampling approach was adopted in selecting the households for the socioeconomic survey. Transects were randomly laid across the neighborhood. For each transect, a house was randomly 
selected within a 50-m radius at the starting point and subsequently every $200 \mathrm{~m}$ along the transect. One adult individual present in the selected house was interviewed.

Overall, 96 representatives of urban households were interviewed using semi-structured questionnaires. The demographic characteristics of the respondents are presented in Table 1 . About $55 \%$ of the respondents were females, $44 \%$ lived in low-income neighborhoods, $30 \%$ in high-income neighborhoods, and the rest in middle-income neighborhoods. Lack of interest and high bureaucratic hurdles in the middle- and high-income neighborhoods accounted for the low participation rates. About $17 \%$ of the respondents lived in government-owned houses, $23 \%$ in rented private houses, while $60 \%$ lived in family/self-owned houses. Roughly $62 \%$ were in informal employment, $33 \%$ were formerly employed, while $5 \%$ were unemployed. The educational background of the respondents was $37 \%$ secondary, $30 \%$ tertiary, and $30 \%$ primary or basic education, while the remaining $3 \%$ had never been to school.

Table 1. Socioeconomic characteristics of the study sample, $N=96$.

\begin{tabular}{|c|c|c|}
\hline Socioeconomic Variables & Number & Percent (\%) \\
\hline \multicolumn{3}{|l|}{$\begin{array}{l}\text { Neighborhood } \\
\text { characteristics }\end{array}$} \\
\hline High income & 29 & 30.21 \\
\hline Middle income & 25 & 26.04 \\
\hline Low income & 42 & 43.75 \\
\hline \multicolumn{3}{|l|}{ Gender } \\
\hline Female & 53 & 55.21 \\
\hline Male & 43 & 44.79 \\
\hline \multicolumn{3}{|l|}{ House ownership } \\
\hline Family & 57 & 59.38 \\
\hline Government & 17 & 17.17 \\
\hline Rented & 22 & 22.92 \\
\hline \multicolumn{3}{|l|}{ Age range (years) } \\
\hline $20-40$ & 54 & 56.25 \\
\hline $40-60$ & 32 & 33.33 \\
\hline$>60$ & 10 & 10.42 \\
\hline \multicolumn{3}{|l|}{ Employment } \\
\hline Formal & 32 & 33.33 \\
\hline Informal & 59 & 61.46 \\
\hline Informal & 5 & 5.21 \\
\hline \multicolumn{3}{|l|}{ Education } \\
\hline Primary & 29 & 30.21 \\
\hline Secondary & 35 & 36.46 \\
\hline Tertiary & 29 & 36.46 \\
\hline Uneducated & 3 & 3.13 \\
\hline
\end{tabular}

Verbal informal consent of the respondents was obtained from each individual who participated in the study, and the researchers adhered to appropriate international ethical guidelines. The aim and purpose of the study was explained to selected participants. The questionnaire used during the interviews was designed to gather data about the socioeconomic characteristics of the respondents, their interest in cultivating fruit trees and promoting urban forestry, as well as on their views about the urban forest and fruit tree cover in the city. The common tree fruits consumed among urbanites were also investigated. In all, about 15 questions were included in each questionnaire. In addition, the trees and shrubs present in the compounds of the selected houses were inventoried. 


\subsection{Data Analysis}

Patterns of species diversity were analyzed using two types of diversity, i.e., $\alpha$-diversity and $\beta$-diversity, and also evenness. Two aspects of $\alpha$-diversity were analyzed, the first being species richness (S), which is defined as the number of species per unit sample plot or land use. Because $S$ can be exaggerated by the presence of rare species, $\alpha$-diversity was also measured with the Simpson's diversity index (D) (Equation (1)) [38]. It is a weighted expression of species richness and abundance of each species in the population and is calculated as

$$
\mathrm{D}=1-\frac{\sum n(n-1)}{N(N-1)}
$$

where $\Sigma=$ summation (total), $n=$ number of individuals of each species, and $N=$ the total number of individuals of all species in the population.

Evenness, defined as the relative abundance of species per unit area, was used to measure the similarity of relative abundance of species within sample plots (Equation (2)) [38]. It was estimated with the Pielou's evenness index (J) as

$$
\mathrm{J}=\frac{H}{S}
$$

where $H=$ Shannon diversity index and $S$ is species richness as previously defined.

Chi-square test was conducted on abundance, S, D and J among land use and neighborhood types using SAS.

Beta $(\beta)$ diversity was calculated to determine species turnover or the extent to which species diversity differs among land uses and neighborhood types within Accra. Various measures of $\beta$-diversity have been proposed. However, in the present study, Whittaker's diversity index $\left(\beta_{\mathrm{w}}\right)$ was used because it is widely regarded as a simple but highly effective measure of $\beta$-diversity [39]. It was calculated as:

$$
\mathrm{B}_{\mathrm{w}}=\frac{S_{\text {total }}}{S_{\text {ave }}}
$$

where $S_{\text {total }}=$ overall species richness of the city and $S_{\text {ave }}=\alpha$-diversity for each land use or neighborhood type.

In addition, correspondence analysis was applied to the data to illustrate floristic relationships between plant communities, land uses, and neighborhood types. Neighborhood type and land use type were considered nominal variables, while species abundance was a continuous variable. Analysis was conducted for all species and food-bearing tree species in Accra. A desk study was used to extract concentrations of some of the essential micronutrients supplied by these trees within Accra.

Descriptive statistics, such as percentages and frequencies, were used to analyze the data obtained from the questionnaires. Bar charts were generated using Microsoft Excel. In addition, we used a binomial generalized linear model (GLM) to determine whether respondent socioeconomic characteristics influence their views about urban fruit tree cover and their interest in promoting urban food forestry in Accra. More specifically, logistic regression was used to determine whether neighborhood type and other socioeconomic variables had an effect on the interest in cultivating fruit trees and promoting urban forestry. The dependent variable is binary, i.e., 1 if the respondent is interested in cultivating trees and 0 otherwise. Binary response data can be accommodated using a fixed-effects or random-effects logit model:

$$
\operatorname{Logit}\left(Y_{i}\right)=L N(p / 1-p)=B_{0}+B_{1} X_{1}+B_{2} X_{2}+\ldots \ldots+X_{n} B_{n}
$$

where $Y_{i j}$ denotes the ith survey response in the jth neighborhood type, $B_{0}$ and $B_{1}$ are coefficients to e estimated in the regression step, $X_{i, j}$ is a vector of independent variables (e.g., neighborhood type, household size, sex of respondents etc.). 


\section{Results}

\subsection{Overall Woody Species Diversity}

A total of 798 trees and shrubs belonging to 70 species and 30 families were recorded during the period of survey. There was a significant difference in species richness $\left(\chi_{4}^{2}=33.4, p<0.0001\right)$ and abundance $\left(\chi_{4}^{2}=362.4, p<0.0001\right)$ for all trees among land use types (Table 2), although only the latter was significantly different $\left(\chi_{4}^{2}=267.8, p<0.0001\right)$ with respect to neighborhood types (Table 3). Home gardens and institutional compounds had the highest Simpson's diversity index and Pieluo's evenness values among other land uses. Similarly, low-income neighborhoods had the highest Simpson's index and Pieluo's evenness of 0.96 and 0.93, respectively, among neighborhood types (Table 3). From i-tree canopy analysis, the tree cover increased with the wealth status of the neighborhood. JT and NM had a tree cover of $10.2 \pm 4.15 \%$ and $14.0 \pm 5.29 \%$, AD and KN had $30.0 \pm 10.0 \%$ and $37.5 \pm 7.65 \%$, while EL and RR had $46.7 \pm 6.44 \%$ and $60.9 \pm 5.88 \%$ of the total neighborhood land area, respectively.

Table 2. Woody tree species richness, abundance, Simpson's diversity index, and Pielou's evenness among land uses in Accra.

\begin{tabular}{ccccc}
\hline Land Use & Richness & Abundance & Simpson's D & Pielou's Evenness, J \\
\hline Cemetery & 12.0 & 68.0 & 0.496 & 1.247 \\
Institutional compound & 33.0 & 144.0 & 0.957 & 2.945 \\
Home garden & 47.0 & 368.0 & 0.945 & 3.149 \\
Park & 29.0 & 91.0 & 0.910 & 2.800 \\
Street & 12.0 & 127.0 & 0.829 & 1.870 \\
Accra total & 70.0 & 798.0 & 0.950 & 3.337 \\
Chisq $\left(\chi^{2}\right)$ & 33.4 & 362.36 & 0.163 & 0.406 \\
$p$-value & $<\mathbf{0 . 0 0 0 1}$ & $\mathbf{< 0 . 0 0 0 1}$ & 0.997 & 0.982 \\
\hline
\end{tabular}

Note: Bold numbers: highlighting areas where comparisons were statistically significant.

Table 3. Woody tree species richness, abundance, Simpson's diversity index, and Pielou's evenness among neighborhood types in Accra.

\begin{tabular}{ccccc}
\hline Neighborhood & Abundance & Richness & Simpson's D & Pielou's Evenness, J \\
\hline High income & 502 & 42 & 0.93 & 0.80 \\
Middle income & 215 & 33 & 0.92 & 0.86 \\
Low income & 131 & 35 & 0.96 & 0.93 \\
Chisq $\left(\chi^{2}\right)$ & 267.8 & 1.22 & 0.001 & 0.01 \\
$p$-value & $<\mathbf{0 . 0 0 0 1}$ & 0.544 & 0.999 & 0.995 \\
\hline
\end{tabular}

Note: Bold number: highlighting areas where comparisons were statistically significant.

A total of 3.4 ha was sampled in home gardens and institutional compounds in the six neighborhoods. The sampled area coverage among neighborhoods was $29 \%$ in EL, 26\% in RR, 20\% in $\mathrm{KN}, 8 \%$ in $\mathrm{AD}, 9 \%$ in NM, and 7\% in JT. In addition, about 0.30 and 0.34 ha of land were sampled in cemeteries and parks, respectively. No park was located in either of the study neighborhoods.

\subsection{Food-Tree Species Diversity}

About half of the total number of trees enumerated (798) in this study had edible components (i.e., leaves or fruits) and belonged to 22 species and 17 families. Both species richness and abundance were significantly different among land uses (Table 4), while the former was not significantly different among neighborhood types (Table 5). Cemetery had the highest Simpson's index and Pielou's evenness values of 0.905 and 0.963 , respectively, owing to its relatively low species richness and abundance. Meanwhile, food trees constituted only $10 \%$ of all the trees in cemeteries while the highest proportion 
among land uses was $66 \%$ in home gardens. The Simpson's diversity index and Pielou's evenness were highest in low income neighborhoods compared to the other neighborhood types (Table 5).

Table 4. Food-bearing tree diversity of different land use types in Accra, Ghana.

\begin{tabular}{ccccccc}
\hline Land Use & Richness & Abundance & Simpson's D & Pielou's J & \% Fruit Trees & \% Fruit Tree Species \\
\hline Cemetery & 5.0 & 7.0 & 0.905 & 0.963 & 10.3 & 41.7 \\
IC & 12.0 & 76.0 & 0.877 & 0.873 & 52.8 & 36.4 \\
HG & 19.0 & 243.0 & 0.889 & 0.821 & 66.0 & 40.4 \\
Park & 7.0 & 19.0 & 0.819 & 0.868 & 20.9 & 24.1 \\
Street & 3.0 & 43.0 & 0.135 & 0.271 & 33.9 & 25.0 \\
Total & 22.0 & 388.0 & 0.867 & 0.761 & 48.6 & 31.4 \\
Chisq $\left(\chi^{2}\right)$ & 17.9 & 476.6 & 0.606 & 0.4063 & 56.3 & 08.5 \\
$p$-value & $\mathbf{0 . 0 0 1 3}$ & $<\mathbf{0 . 0 0 0 1}$ & 0.962 & 0.982 & $<\mathbf{0 . 0 0 0 1}$ & $\mathbf{0 . 0 7 5 8}$ \\
\hline
\end{tabular}

Note: Bold numbers: highlighting areas where comparisons were statistically significant. IC $=$ Institutional compound, $\mathrm{HG}=$ Home garden .

Table 5. Food-tree species diversity and abundance among neighborhood types in Accra.

\begin{tabular}{ccccc}
\hline Neighborhood & Abundance & Richness & Simpson's D & Pielou's J \\
\hline High income & 198 & 13 & 0.93 & 0.80 \\
Middle income & 122 & 12 & 0.92 & 0.85 \\
Low income & 69 & 16 & 0.96 & 0.90 \\
Chisq $\left(\chi^{2}\right)$ & 64.8 & 0.634 & 0.00 & 0.01 \\
$p$-value & $<\mathbf{0 . 0 0 0 1}$ & 0.728 & 0.999 & 0.997 \\
\hline
\end{tabular}

Note: Bold number: highlighting areas where comparisons were statistically significant.

\subsection{Species Composition and $\beta$-Diversity of Food-Tree Species}

Woody species of various land uses in Accra were separated using correspondence analysis (Figure 1). Dimension 1 explained 34.1\% of the variation and appears to be determined by species such as Veitchia merrillii, Zanthoxylum zanthoxyloides, and Plumera alba in the parks, and Millingtonia hortensis and Khaya senegalensis in the streets; dimension 2 explained $30.1 \%$ of the variation and is determined more by food-bearing tree species such as Persea americana, Vernonia amygdalina, Moringa oleifera, and Elaeis guineensis, etc., in the home gardens and by Millingtonia hortensis and Albizia lebbeck in the streets. Institutional compounds and home gardens are grouped together, as are parks and cemeteries, with streets completely separated from these groups.

Woody species separation among neighborhood types followed a different pattern (Figure 2). Dimension 1 explains $57.1 \%$ of the variation and was influenced more by low-income and high-income neighborhoods. Dimension 2 explains $42.9 \%$ of the variation and was determined more by the middle-income neighborhoods. Species such as Artocarpus incisus, Cassia spectabilis, Citrus reticulata, and Citrus limon, as well as Musa spp., Vernonia amygdalina, and Gliricidia sepium, etc., also strongly influenced dimension 2 . 


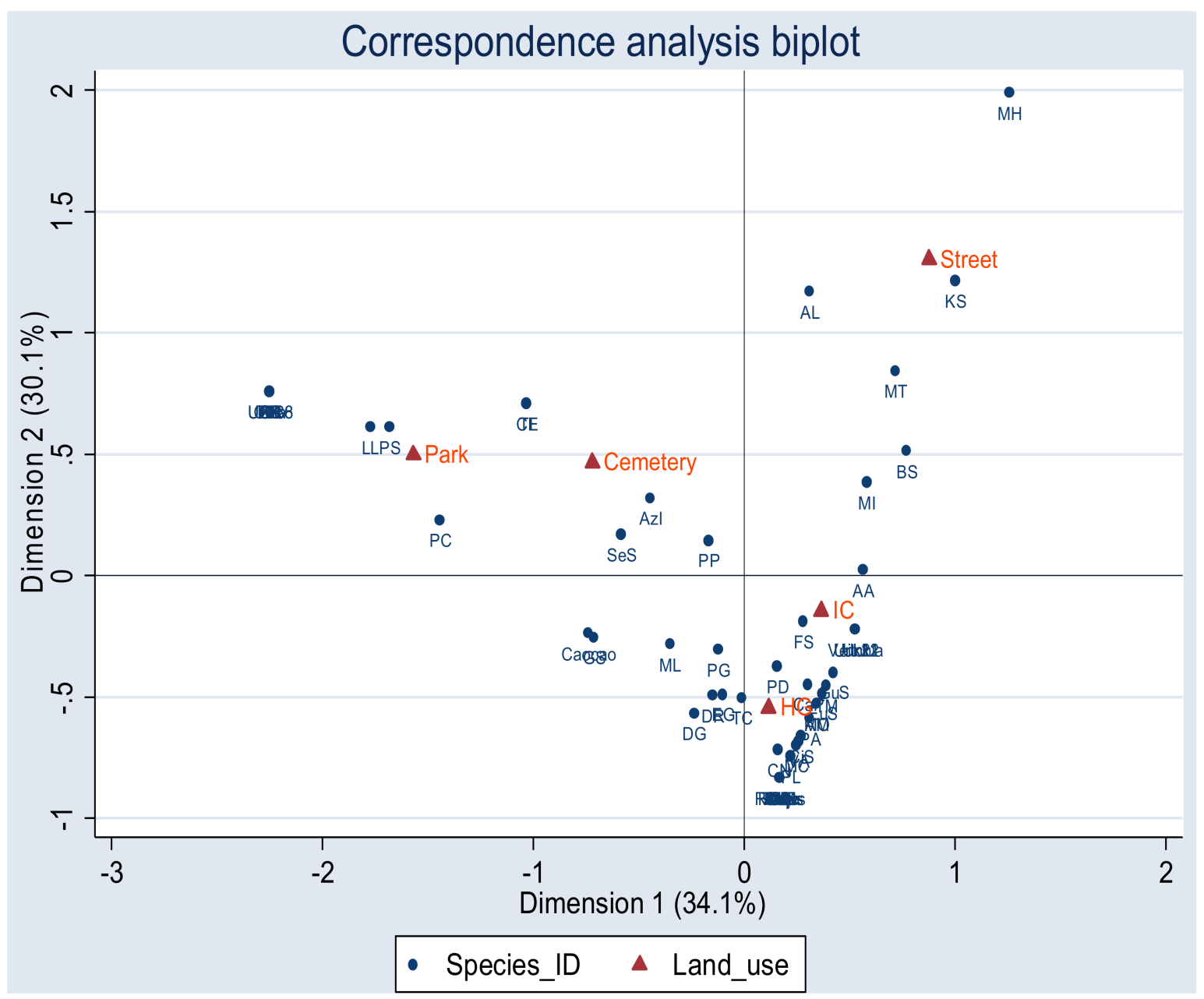

Figure 1. Correspondence analysis biplot of woody species among land uses in Accra. Land_use: $\mathrm{IC}=$ Institutional compound, $\mathrm{HG}=$ home garden. Species: $\mathrm{AA}=$ Acacia auriculiformis, $\mathrm{AM}=$ Acacia mangium, $\mathrm{AL}=$ Albizia lebbeck, $\mathrm{AO}=$ Anarcadium occidentalis, $\mathrm{AnM}=$ Annona muricata, $\mathrm{AT}=$ Antiaris toxicaria, $\mathrm{AI}=$ Artocarpus incisus, AS = Araucaria spp., Azl = Azadirachta indica, BS = Blighia sapida, Cap = Calotropis procera, $\mathrm{CaP}=$ Carica papaya, $\mathrm{CaE}=$ Casuarina equisetifolia, $\mathrm{CS}=$ Cassia spectabilis, $\mathrm{CP}=$ Ceiba pentandra, $\mathrm{CeN}=$ Cestrum norturnum, $\mathrm{CE}=$ Chlorophora excelsa, $\mathrm{CL}=$ Citrus limon, $\mathrm{CR}=$ Citrus reticulata, $\mathrm{CiS}=$ Citrus sinensis, $\mathrm{CN}=$ Cocos nucifera, $\mathrm{CC}=$ Cola caricifolia, $\mathrm{DR}=$ Delonix regia, DG = Dialium guineense, EG = Elaeis guineensis, EuS = Eucalyptus spp., FB = Ficus bonsai, FS = Ficus spp, $\mathrm{GS}=$ Gliricidia sepium, GA = Gmelina arborea, GuS = Guaiacum sanctum, HF = Holarrhena floribunda, $\mathrm{KS}=$ Khaya senegalensis, $\mathrm{LL}=$ Leucaena leucocephela, $\mathrm{MI}=$ Mangifera indica, MT = Millettia thonningii, $\mathrm{MH}=$ Millingtonia hortensis, $\mathrm{MC}=$ Morinda citrifolia, $\mathrm{ML}=$ Morinda lucida, $\mathrm{MO}=$ Moringa oleifera, $\mathrm{MB}=$ Musa balbisiana, $\mathrm{NL}=$ Newbouldia laevis, $\mathrm{PP}=$ Peltophorum pterocarpum, $\mathrm{PA}=$ Persea americana, $\mathrm{PC}=$ Pinus caribaea, $\mathrm{PD}=$ Pithecellobium dulce, $\mathrm{PS}=$ Pithecellobium saman, PlA = Plumera alba, $\mathrm{PL}=$ Polyalthia longifolia, $\mathrm{PG}=$ Psidium guajava, Ricinus = Ricinus communis, $\mathrm{RR}=$ Roystonia regia, $\mathrm{SeS}=$ Senna siamea, $\mathrm{SR}=$ Sterculia rhinopetala, $\mathrm{TI}=$ Tamarindus indica, $\mathrm{TC}=$ Terminalia catappa, $\mathrm{TM}=$ Terminalia montalis, Caocao $=$ Theobroma cacao, Thuja $=$ Thuja orientalis, Veitchia = Veitchia merrillii, $\mathrm{VA}=$ Vernonia amygdalina, $\mathrm{ZZ}=$ Zanthoxylum zanthoxyloides. 




Figure 2. Correspondence analysis biplot of species in three neighborhood types in Accra. $\mathrm{HI}$-high-income, MI-middle-income, and LI-low-income neighborhood types. Names of species are as in Figure 3.

Beta diversity analysis revealed that $75 \%$ of the species in the cemetery were similar to those of institutional compounds and home gardens while only $50 \%$ and $58 \%$ were similar to those of streets and parks, respectively. In contrast, $30 \%$ and $42 \%$ of species in IC were found in streets and parks, respectively, whereas $76 \%$ were in home gardens. About $75 \%$ and $55 \%$ of the species in streets and parks, respectively, were also in home gardens while $50 \%$ of the species in streets were also in home gardens. As a consequence of these similarities, Beta $\left(\beta_{\mathrm{W}}\right)$ diversity estimates between land uses were not significantly different, ranging between 1.4 (IC and HG) and 1.7 (HG and street, park and street etc.).

\subsection{Nutrient Composition of Selected Common Urban Food-Tree Species in Accra}

The most common food-bearing tree species in the survey based on abundance included Mangifera indica (mango), Elaeis guineensis (oil palm), Cocos nucifera (coconut), Carica papaya (pawpaw), Terminalia catappa (Indian almond), and Moringa oleifera. The five least abundant species were Tamarindus indica, Artocarpus incisus, Citrus limon, C. reticulata, and Blighia sapida.

The food-bearing tree species contain a range of major and micronutrients including vitamins essential for human wellbeing. Tree foods were consumed directly as fruit pulp, leaves, nuts, seeds, and juices like coconut water while others required further processing before being consumed. All the species enumerated are high in proteins, carbohydrates, crude fiber, crude fat, ash, and moisture 
content, although these vary among species. On average, protein, carbohydrate, fiber, fat, ash, and moisture content were 8.12, 39.5, 12.64, 10.3, 4.8 and $27.4 \mathrm{~g} / \mathrm{g}$, respectively. This indicates that tree foods could play a critical role in meeting the dietary needs of urbanites. In addition, the common minerals in the fruits, leaves and seeds of these tree species included calcium $(\mathrm{Ca})$, potassium $(\mathrm{K})$, sodium $(\mathrm{Na})$, magnesium $(\mathrm{Mg})$, zinc $(\mathrm{Zn})$, iron $(\mathrm{Fe})$, iodine $(\mathrm{I})$, copper $(\mathrm{Cu})$, manganese $(\mathrm{Mn})$, and molybdenum $(\mathrm{Mo})$. At least $50 \%$ of the food tree species listed in Accra supply $8 \%$ of the above nutrients (Table 6). At least 10 tree species can supply $\mathrm{Cu}$ and $\mathrm{Mn}$ while only two species (Dialium guineensis and Elaeis guineensis) supply I. Furthermore, a few of the tree species listed in Accra have the potential to supply niacin, riboflavin, thiamine, and the vitamins K, E, C, and A. Leaves and fruits of Vernonia amygdalina, Tamarindus indica, and Annona muricata can supply niacin. Mean concentrations of each mineral and the number of tree species bearing these nutrients are shown in Table 6. There are wide variations in the nutritional composition and concentrations of these nutrient elements among species. Of the sampled food-bearing trees, $6 \%$ supply niacin, $52 \%$ supply P, $63 \%$ supply Cu while over $80 \%$ supply all the other basic minerals (Table 6). About $98 \%$ of the trees provide energy when eaten as fruits, nuts, seeds, leaves, oils, and flowers. Overall $80 \%$ of the food bearing trees sampled is eaten as fruits, $31 \%$ as nuts, $28 \%$ as oils, $9 \%$ as leaves, and $29 \%$ as seeds.

\subsection{Perceptions of Urban Forest Cover and Interest in Promoting Urban Forestry in Accra}

In total, 58 of the 96 respondents $(60 \%)$ expressed an interest in cultivating food trees and promoting urban forest expansion activities in Accra. The results show that neighborhood type and perceptions about the food-tree/forest cover significantly influenced the likelihood of one being interested in cultivating trees (Table 7). Results of the odd ratio analysis further reveal that people in high-income and middle-income neighborhoods were respectively 22 and seven times more likely to be interested in cultivating food/forest trees in Accra compared to people in low-income/slum neighborhoods. Overall interest in cultivating food-bearing trees in the high-income, middle-income, and low-income neighborhoods was respectively shown by $69 \%, 56 \%$ and $57 \%$ of the respondents interviewed. Similarly, people who perceived the city to be low in forest/tree cover were more likely than not to be interested in cultivating forest/food trees compared to people who perceived the tree cover of Accra to be high.

Level of awareness of urban forestry and urban food forestry in Accra was examined. The qualitative results reveal that level of awareness was only marginally different for both males and females (Figure 3). Nearly $100 \%$ of both male and female respondents were enthusiastic about promotion of urban forestry in Accra. The perception of people in high-income neighborhoods about the forest and fruit forest cover of Accra as well as the enthusiasm to promote urban forestry was higher than in the other neighborhood types (Figure 4). About $57 \%$ and $54 \%$ of the respondents in low-income neighborhoods had some level of awareness of urban forest and urban food-forest cover of Accra, respectively. Low-income neighborhoods were the least likely to promote urban forestry $(95 \%)$ compared to other neighborhood types. 
Table 6. Mean, minimum, and maximum micronutrient and selected vitamins in food-tree species in Accra, Ghana.

\begin{tabular}{|c|c|c|c|c|c|c|c|c|c|c|c|}
\hline & Niacin & $\mathbf{K}$ & $\mathrm{Ca}$ & $\mathbf{P}$ & Zn & $\mathrm{Na}$ & $\mathrm{Mg}$ & Fe & $\mathrm{Cu}$ & Mn & Iodine (I) \\
\hline Number of species & 3.0 & 14.0 & 16.0 & 12.0 & 15.0 & 13.0 & 19.0 & 16.0 & 10.0 & 10.0 & 2.0 \\
\hline Proportion of sampled food tree species (\%) & 14.3 & 66.7 & 76.2 & 57.1 & 71.4 & 61.9 & 90.5 & 76.2 & 47.6 & 47.6 & 9.5 \\
\hline Number of trees & 23 & 310 & 328 & 202 & 321 & 337 & 364 & 368 & 238 & 259 & 65 \\
\hline Proportion of sampled food trees (\%) & 5.9 & 79.9 & 84.5 & 52.1 & 82.7 & 86.9 & 93.8 & 94.8 & 61.3 & 66.8 & 16.8 \\
\hline Mean & 1.2 & 275.3 & 62.8 & 232.5 & 21.2 & 40.2 & 54.8 & 4.1 & 8.9 & 5.3 & 18.8 \\
\hline Minimum & 1.7 & 0.1 & 0.1 & 0.0 & 0.0 & 0.0 & 0.0 & 0.0 & 0.0 & 0.0 & 4.3 \\
\hline Maximum & 1.9 & 673.5 & 250.1 & 1411.0 & 193.9 & 169.5 & 347.0 & 16.2 & 70.3 & 29.2 & 33.3 \\
\hline
\end{tabular}

K—potassium, Ca—calcium, P—phosphorous, Zn—zinc, Na—sodium, Mg-magnesium, Fe-iron, $\mathrm{Cu}-$ copper, Mn—manganese.

Table 7. Logistic regression of factors influencing interest in cultivating food-bearing trees in Accra, Ghana.

\begin{tabular}{cccc}
\hline Variable & DF & Wald Chi-Square & Pr > ChiSq \\
\hline X1-Neighborhood type & 2 & 6.8959 & $\mathbf{0 . 0 3 1 8}$ \\
X2-House ownership & 3 & 0.3936 & 0.9416 \\
X3-Age range & 2 & 0.8703 & 0.6472 \\
X4-Sex of respondent & 1 & 0.1161 & 0.7333 \\
X5一Household size & 16 & 6.7629 & 0.9776 \\
X6-Employment of household head & 2 & 2.4212 & 0.2980 \\
X7-Level of education of respondent & 3 & 3.5376 & 0.3159 \\
X9-Satisfaction with quality and & 1 & 1.4275 & 0.2322 \\
quantity of food & 1 & 1.4547 & 0.2278 \\
X10-Vegetation cover of Accra & 1 & 7.0229 & $\mathbf{0 . 0 0 8 0}$ \\
X11-Food/Fruit tree cover of Accra & 3 & 5.5055 & 0.1383 \\
X12-Vegetation cover of neighborhood & 3 & & \\
\hline
\end{tabular}

$* *(*)$ Significant at $p=0.05$ 


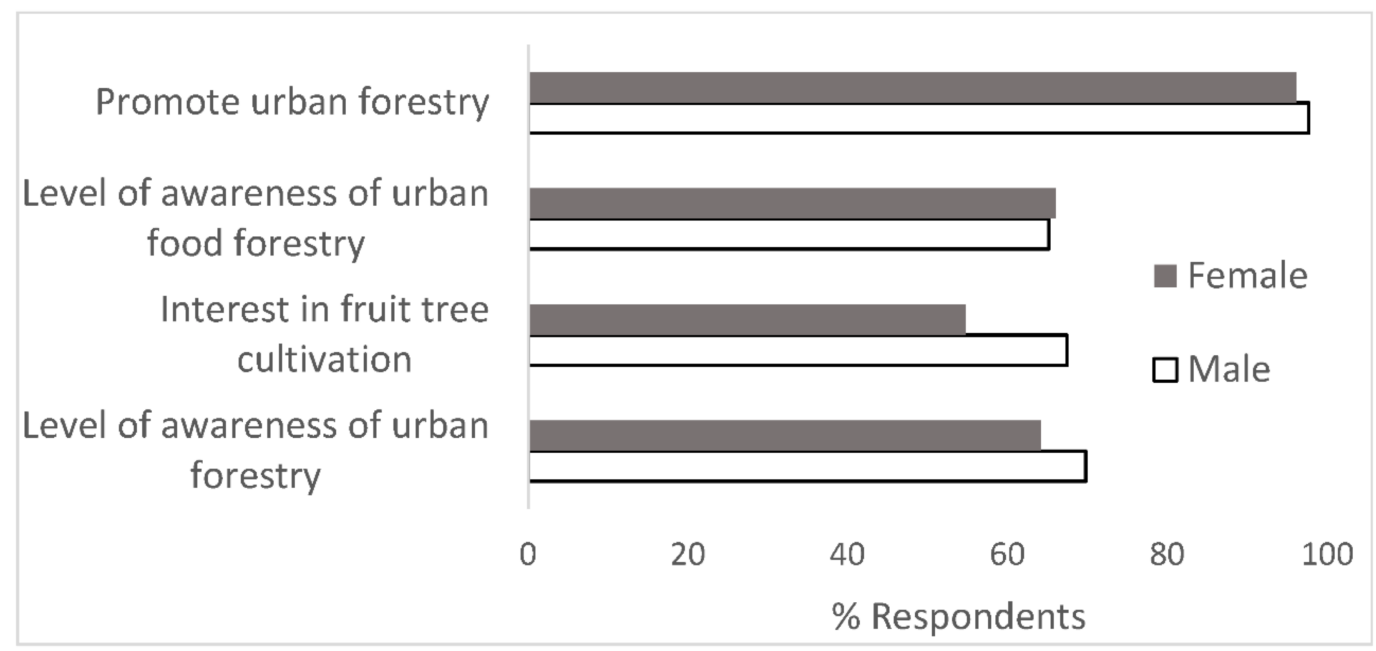

Figure 3. Views of male and female respondents on attributes of urban forestry in Accra, Ghana.

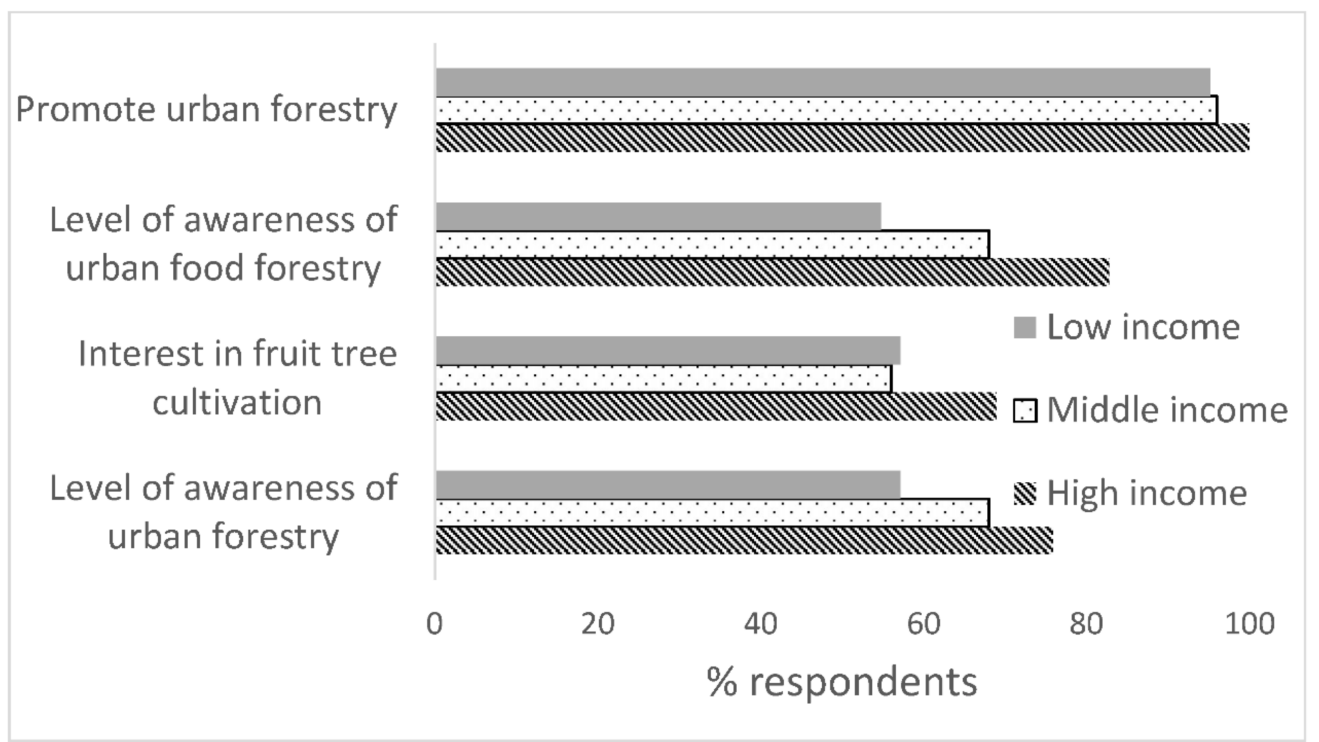

Figure 4. Views of respondents on level of awareness of the urban forest and promotion of urban forestry among neighborhood types in Accra, Ghana.

\section{Discussion}

\subsection{Forest and Food-Tree Species Composition and Diversity}

In the current study, we found that the city of Accra supports a fairly high woody species diversity, and that this diversity was significantly stratified among the vegetated land use types and neighborhood types (Tables 2 and 3). We further found that species such as Azadirachta indica (neem), Mangifera indica (mango), Elaeis guineensis (palm), Cocos nucifera (coconut), and Polyalthia spp. (weeping willow) were the five most common species in the city. These findings are consistent with findings of floral diversity studies in Abuja, Nigeria, and the Valley View University campus near Accra where woody species richness of 69 and 53, respectively, were observed [32,40]. However, species richness and diversity in the current study were lower than the 176 species and Shannon index of 3.70 reported in Kumasi [9,41] and the 297 tree species in Lome, Togo [42]. Yet the diversity and richness values in Accra conform with recent findings that cities in Africa support relatively high diversity even when compared to neighboring natural forest [40-43]. Although cities are typically located in biodiversity hotspots [44,45], their high diversity, intercity disparities in diversity, and species richness are inherent 
in the morphology and age of the city, and the natural ecological factors as well as building and population densities. Accra is located in the coastal savannah zone with many of the (common) species recorded in the current study classified as savannah species [32,46]. This explains its lower richness and diversity values compared to cities located in high forest zones, which possibly have lower population and building densities.

The within-city differences in woody species diversity and richness among land uses may be ascribed to several factors, including governance, ecological, and socioeconomic conditions as well as the culture of the people. Home gardens harbor the highest species diversity and compositional differences. Species richness and diversity of home gardens in Accra are similar to those of home gardens in cities such as Rio Claro, Brazil [47], and directly manifest their multifunctional and structural complexities [48] underpinned by various socio-ecological constraints [47,49]. Home gardens in Accra are varied in size and severely fragmented, and maintained for alimentary, fuelwood, aesthetics, and environmental conservation purposes. Consequently, their diversity reflects the diversity of the individuals residing in the city and their interests. On the other hand, parks, streets, and cemeteries are directly under the control and management of the local government. Diversity in these land uses is comparatively lower because these were planted with a few exotic tree species for specific limited functions. While Azadirachta indica predominates in the cemeteries, the most common species in parks and on streets were Gliricidia sepium and Millingtonia hortensis, respectively. Their primary functions are recreation (aesthetics), shade, and environmental conservation.

The current study also found that species abundance and richness were much higher in high-income neighborhoods compared to other neighborhood types while the reverse was true for Simpson's diversity index and Pielou's evenness. These findings corroborate previous studies that found that high-income neighborhoods had higher biodiversity than low-income neighborhoods $[50,51]$. This coupled with the low tree cover in low-income neighborhoods should be an issue of concern for policy makers, as residents in these low income neighborhoods are less likely to access and enjoy sufficient environmental benefits emanating from urban forest and tree diversity in these third world cities.

\subsection{Urban Forest-Tree Diversity and Food/Nutritional Security}

Residents of Accra, like their compatriots in other West African cities, have a low fruit and vegetable consumption culture [11]. While high fruit and vegetable prices deprive many of their preferred balanced diet (lack of access), unavailability of food resources can constrain food security in a given area. In the light of this, we explored the availability and distribution of food-bearing tree species in three neighborhood types within Accra. It was found that $31 \%$ of the tree species and nearly $50 \%$ of all trees enumerated were food bearing (Table 4). About $51 \%$ of these food trees were in the high-income neighborhoods and $18 \%$ in low-income neighborhoods. In contrast, food-tree diversity was highest in the low-income neighborhoods compared to the other neighborhood types. Similar to the findings of the present study, 18 food-bearing species were recorded on the campus of the University of Port Harcourt, Nigeria [22]. Our findings are also consistent with previous findings that plant species useful for food, medicines and other provisioning services were more frequently found in gardens of poorer residents than in those of wealthier residents [49]. Considering that increasing neighborhood wealth correlates with increasing vegetation cover [30], we surmise that the low tree abundance in low-income neighborhoods may be due to lack of space resulting from legacy effects of past development and lack of interest in cultivating/managing trees. Whereas poorer urbanites maintain small home gardens for provisioning of basic services such as alimentary, medicinal, income, and livelihood services which reflect their rural origins and cultural heritage, the relatively wealthier class invest in large home gardens for their aesthetic and recreational functions [47,49]. These disparities in green cover and food-tree populations among neighborhood types could have dire tree-food availability consequences especially in low-income neighborhoods where over $70 \%$ of the income is mostly spent on purchasing staple foods. The foregoing emphasizes the need for scientists and policy makers to consider judicious 
and scientific policies that ensure equity in the distribution of green spaces and biodiversity among neighborhoods in order to avoid issues of resource and environmental injustice [8,9]. In low-income neighborhoods, opportunities exist with respect to planting food-bearing trees along streets, within some family house compounds, and in the pockets of bare areas dotted around the neighborhoods.

Analysis of the nutrient contents and composition of food components of these tree species revealed that they can supply a very large amount of basic nutrients (proteins, carbohydrates, fats, fiber), vitamins, and mineral nutrients. Average nutrient concentrations of the selected minerals found were fairly high (Table 6). The edible parts of these trees included fruits, leaves, nuts, seeds, oils, and flowers. Our findings corroborate observations by the FAO that home gardens provide families with the non-staples they require all year round [52], and forest-tree products are usually higher in nutrient contents than domesticated crops and staples [18]. However, evidence of resource availability does not necessarily imply access and utilization. In urban Ghana, diets tend to be dominated by animal-based products of rice, pasta, meat, and fish mixed and less of fruits and vegetables [11,27]. Although such dietary diversification reduces the risk of communicable diseases such as Type 2 diabetes among adults, it is only partially true in most sub-Saharan African cities [53]. About $67 \%$ school-age children in parts of Accra are malnourished, suffering at least one nutritional deficit of being stunted, underweight or anemic [28]. Although energy intake of these school kids was adequate, there was a conspicuously low $\mathrm{Ca}$ intake [28]. Moreover, deficiencies in minerals such as $\mathrm{Fe}, \mathrm{Zn}$, and vitamin $\mathrm{A}$ in urban diets around the world are not uncommon [54]. In contrast, our current study reveals that $76 \%$ of the food-tree species contain high concentrations of Ca $(0.05-250 \mathrm{mg} / 100 \mathrm{~g}), 76 \%$ contain $\mathrm{Fe}(0.0009-16.1 \mathrm{mg} / 100 \mathrm{~g})$ and $71 \%$ contain $\mathrm{Zn}(0.0003-193 \mathrm{mg} / 100 \mathrm{~g})$. Urban forest-tree species therefore are (1) a source of a diversity of healthy food, high in micronutrients and fiber, and low in fats and sugars; (2) high in food of cultural value and contribute significantly to the local food systems and sovereignty; and (3) help to fill seasonal and cyclical food gaps and act as a "safety net" when there is shortage [17]. The high incidences of nutrient deficiencies among urbanites in Ghana vis-à-vis the relatively high abundance of nutritious food-tree species in Accra suggests that urban tree foods may not be accessible to all.

Besides, urban food trees can provide several ecosystem services and goods. In Bobo Dioulasso, Burkina Faso, mango and cashew plantations have the potential to contribute $6 \%$ of the monthly food expenditures of the involved poor households, reduced the run-off co-efficient by $4 \%$ (reduction in flood risks and increased infiltration), sequestered over 1835.56 tons of $\mathrm{CO}_{2}$ per ha, and significantly reduced ambient temperatures [55]. Considering this wide range of benefits, we suggest populating school compounds and open spaces in cities, particularly Accra, with food-bearing trees and encouraging the consumption of the fruits among the urbanites. Policies and strategies to expand the urban food forest cover, extend shelf-life of fruits, and enhance the consumption of fruits in African cities are critical.

\subsection{Perceptions and Interest in Promoting Urban Food Forest}

Restoring, protecting, and enhancing green infrastructure (forest and woodlands) in urban areas are not only ecologically and socially desirable, they are also economically viable [56]. As outlined above, the urban forest has the potential to provide a myriad of ecosystem goods and services, food security, climate regulation, aesthetics, regulation of storm run-off, reduction in erosion, and other supporting services etc. [57,58]. Within Africa, research on social and economic aspects of urban forestry are rather limited [59]. Our present study reveals that perceptions about the level of awareness of the urban forest in Accra and the willingness to promote urban forestry did not differ significantly among key socioeconomic variables, i.e., gender, sex of respondents, neighborhood type, type of house ownership, household size. At least $70 \%$ of the respondents in the high-income neighborhoods thought there is high awareness of urban forest(ry) in the city, with about $70 \%$ of the residents with high-school education and below asserting likewise. However, cultivating food-bearing trees in the city was probably significantly influenced by the neighborhood's wealth status and the view about the forest cover (Table 7). These findings agree with findings that $99 \%$ of respondents in Ibadan, Nigeria, were aware of the urban forest, its benefits and value for their wellbeing, and 
expressed a strong interest in preserving urban forest cover [60]. Proximity to trees/forests and the perceived (dis)incentives associated with forest are strong determinants of perceptions about the urban forest $[60,61]$. Within the Ayawaso East submetropolis of Accra, residents of relatively denser forested areas rank and prioritize urban forest higher than their compatriots in less dense forested areas [62]. Since high-income neighborhoods of most cities are considerably higher in forest/green cover than other neighborhood types $[8,30,63]$, the perceptions of respondents in high-income neighborhoods in the present study are not out of place.

Why the less educated respondents believe there is high awareness level of the urban forest in the city is rather difficult to substantiate, since a lot of these people were located in the low-income and middle-income neighborhoods where tree cover is relatively low. We believe, however, that the issue is due to misinformation and lack of adequate knowledge about what constitutes an urban forest. These urbanites may have been deluded by the presence of the few trees in their neighborhoods coupled with past developmental legacies where old towns such as James/Usher Town were built devoid of green cover [64]. Since colonial times, neighborhoods such as Nima and James Town have been developed haphazardly either with limited planning or overstepping existing plans and laws. These historical patterns, unavailability of space, customary land use systems, and beliefs about a city without nature may have shaped the views of residents in neighborhoods with less forest cover who felt that the few trees in their neighborhoods were enough to meet their basic life quality needs. The situation creates a need for expanding formal educational programs as well as education about trees and forests in cities particularly among residents of low-income neighborhoods in Accra. Educational programs must be multicultural in character, conducted in the local languages using several media platforms, and above all connect people with their trees and green spaces both physically and psychologically [65].

Our findings that residents of high- and middle-income neighborhoods were more likely to plant trees than those in low-income neighborhoods corroborate previous findings. In one city each in Nigeria and Congo D.R., $90 \%$ and $86 \%$ of respondents, respectively, indicated their preference regarding cultivating trees in urban areas and were willing to participate in public tree planting programs [66,67]. People who are well educated, have relatively high income and may live in areas with sufficient land area around their houses are therefore more likely to cultivate trees or participate in public tree planting programs $[63,66,68]$. The high- and middle-income neighborhoods in Accra are occupied by the elites and the wealthy classes of society who have a good judgment of the value of trees and have the resources to plant and care for trees within their homesteads.

Some studies have concluded that people in neighborhoods that are relatively deprived (low income and education levels) are less likely to participate in public tree planting programs $[63,69]$. Reasons why people in low-income neighborhoods seem to be less interested in tree cultivation include (1) lack of space to plant trees; (2) benefits of trees take too long to be realized; (3) trees interfere with building foundations and roofs; (4) tree waste such as falling litter is expensive and time consuming to clean; and (5) some perceive trees or forest in human settlements to be associated with negative incentives such as serving as hideouts for criminals, habitats for dangerous pests, etc.

\section{Conclusions}

The study assessed the urbanites' perceptions and the diversity of urban forest of Accra and its potential to contribute to food security in cities in developing countries. About $31 \%$ of the woody species and nearly $50 \%$ of all tree individuals recorded have the potential to provide food either as fruits, seeds, nuts, leaves, oils, and many others. Home gardens harbor the highest species richness with high-income neighborhoods having high abundance of trees while the highest diversity values for food-tree species were found in low-income neighborhoods. In addition, it was observed that these woody species can serve as sources of several major and micronutrients as well as vitamins essential for addressing hidden hunger issues which frequently affect urbanites in developing countries owing to the changing food culture, high food prices, and overreliance on traditional staples. In particular, more 
than $70 \%$ of the food-tree species in the city could supply critical nutrients such as $\mathrm{Fe}, \mathrm{Zn}, \mathrm{Mo}$, I and Ca. It is concluded that the urban forest is a vital source of food and nutrients and could play a critical role in complementing traditional agricultural practices in the fight against urban food insecurity and malnutrition in Africa.

However, urban food-tree diversity is spatially stratified among neighborhood types, a situation that could lead to environmental and food security injustices. Low-income neighborhoods are particularly disadvantaged in this regard. Therefore, widening socioeconomic inequalities in the city will exacerbate environmental inequality [29], and by default the inequality in the distribution of the urban forest cover. Policies and strategies to address food insecurity through urban forestry must be directed at reducing income and educational inequalities as well as at engaging in massive public and private tree planting exercises in all neighborhoods. Because tree-food production is seasonal, in order to ensure the availability of tree foods all year round it is important to consider the food production seasons of species when selecting species for urban food forest cultivation. Innovative strategies could be adopted to avoid seasonal food and nutritional insecurities within the urban landscape.

The present study restricted its scope to tree products and the perceptions of tree cover and interest in cultivating trees in the city of Accra. A complete perspective of the potential and contribution of urban trees to food security requires a thorough analysis of intra- and intercity urban forest and food security relations. Deliberate policies in favor of food-tree cultivation or urban food forestry as part of measures to address urban food insecurity should be a national and regional priority in Africa. Policies to reduce income and educational inequality in cities are critical to sustaining greener cities, which are ideals enshrined in the sustainable development goals.

Plans for follow-up research include studies to monitor tree-growth responses with respect to neighborhood characteristics and the factors that influence participation in tree planting programs within cities in these developing countries. Urban forest structure and the diversity relationship to urban health will be another primary research focus. It may also be worthwhile to increase sampling efforts and number of neighborhoods in a follow-up study in order to provide more robust data on the dietary pattern and nutritional habits of neighborhoods in relation to environmental quality and vegetation cover.

Author Contributions: Conceptualization, B.F.N. and O.F.; Methodology, B.F.N.; Software, B.F.N.; Validation, B.F.N., N.A.K., R.J., and O.F.; Formal Analysis, B.F.N.; Investigation, B.F.N.; Resources, B.F.N., N.A.K., R.J.; Data Curation, B.F.N.; Writing—Original Draft Preparation, B.F.N.; Writing—Review \& Editing, B.F.N., N.A.K., R.J., and O.F.; Visualization, B.F.N.; Supervision, B.F.N., O.F.; Project Administration, B.F.N.; Funding Acquisition, B.F.N., R.J., and O.F.

Funding: This research was funded by the German Federal Ministry of Education and Research (BMBF) and the German Federal Ministry of Economic Cooperation and Development (BMZ) through the BiomassWeb project, which is coordinated by the Center for Development Research (ZEF), University of Bonn, Germany, and the Forum for Agriculture Research in Africa (FARA) Accra, Ghana.

Acknowledgments: We are grateful to several individuals and institutions for their assistance with data collection and processing. Many thanks to all institutional heads and landlords and landladies in the six neighborhoods of Accra who permitted us to collect vegetation and socioeconomic data on their premises. Our profound gratitude to Jonathan Dabo of CSIR-FORIG for assisting with tree identification, Nadia Danso and Emmanual K. Asare for assisting with data collection. The contributions of the FARA staff who facilitated the paperwork of our operations at FARA are duly acknowledged. We are grateful to the four anonymous reviewers whose comments critically improved the quality of the paper.

Conflicts of Interest: The authors declare no conflict of interest.

\section{References}

1. Frayne, B.; Pendleton, W.; Crush, J.; Acquah, B.; Battersby-lennard, J.; Bras, E.; Chiweza, A.; Fincham, R.; Kroll, F.; Leduka, C.; et al. The State of Urban Food Insecurity in Sourthern Africa; African Food Security Urban Network: Cape Town, South Africa, 2010; ISBN 9780986982019.

2. Baker, J.L. Urban Poverty: A Global View; The World Bank Group: Washington, DC, USA, 2008; Available online: http:/ /www.worldbank.org/urban/ (accessed on 20 September 2017). 
3. Chen, S.; Ravallion, M. Absolute poverty measures for the developing world, 1981-2004. Proc. Natl. Acad. Sci. USA 2007, 104, 16757-16762. [CrossRef] [PubMed]

4. Maxwell, D.; Levin, C.; Armar-klemesu, M.; Ruel, M.; Morris, S.; Ahiadeke, C. Urban Livelihoods and Food and Nutrition Security in Greater Accra, Ghana; IFPRI: Washington, DC, USA, 2000; ISBN 0896291154.

5. CFS/HLPE. Sustainable Forestry for Food Security and Nutrition; Food and Agriculture Organization (FAO): Rome, Italy, 2017.

6. Pimentel, D.; McNair, M.; Buck, L.; Pimentel, M.; Kamil, J. The value of forests to world food security. Hum. Ecol. 1997, 25, 91-120. [CrossRef]

7. Bren d'Amour, C.; Reitsma, F.; Baiocchi, G.; Barthel, S.; Güneralp, B.; Erb, K.-H.; Haberl, H.; Creutzig, F.; Seto, K.C. Future urban land expansion and implications for global croplands. Proc. Natl. Acad. Sci. USA 2017, 114, 8939-8944. [CrossRef] [PubMed]

8. Nero, B.F. Urban Green Spaces Enhance Carbon Sequestration and Conserve Biodiversity in Cities of the Global South: Case of Kumasi, Ghana. Ph.D. Thesis, University of Bonn, Bonn, Germany, 2017.

9. Nero, B.F. Urban green space dynamics and socio- environmental inequity: Multi-resolution and spatiotemporal data analysis of Kumasi, Ghana. Int. J. Remote Sens. 2017, 38, 6993-7020. [CrossRef]

10. Cumming, G.S.; Buerkert, A.; Hoffmann, E.M.; Schlecht, E.; Von Cramon-Taubadel, S.; Tscharntke, T. Implications of agricultural transitions and urbanization for ecosystem services. Nature 2014, 515, 50-57. [CrossRef] [PubMed]

11. Codjoe, S.N.A.; Okutu, D.; Abu, M. Urban Household Characteristics and Dietary Diversity: An Analysis of Food Security in Accra, Ghana. Food Nutr. Bull. 2016, 37, 202-218. [CrossRef] [PubMed]

12. Malabo Montpellier Panel. Nourished: How Africa Can Build a Future Free from Hunger and Malnutrition. Available online: http:/ / www.ifpri.org/publication/nourished-how-africa-can-build-future-free-hungerand-malnutrition (accessed on 12 September 2018).

13. Walsh, C.M.; van Rooyen, F.C. Household food security and hunger in rural and urban communities in the Free State Province, South Africa. Ecol. Food Nutr. 2015, 54, 118-137. [CrossRef] [PubMed]

14. Kengne, A.P.; Bentham, J.; Zhou, B.; Peer, N.; Matsha, T.E.; Bixby, H.; Di Cesare, M.; Hajifathalian, K.; Lu, Y.; Taddai, C.; et al. Trends in obesity and diabetes across Africa from 1980 to 2014: An analysis of pooled population-based studies. Int. J. Epidemiol. 2017, 46, 1421-1432. [CrossRef]

15. FARA. Study of Growth, Structural Change and Total Factor Productivity in Eight African Countries; Pattern Draw Ltd.: Accra, Ghana, 2016.

16. Food and Agriculture Organization (FAO). Towards food Security and Improved Nutrition: Increasing the Contribution of Forests and Trees; FAO: Rome, Italy, 2013.

17. Arnold, M.; Powell, B.; Shanley, P.; Sunderland, T.C.H. EDITORIAL: Forests, biodiversity and food security. Int. For. Rev. 2011, 13, 259-264. [CrossRef]

18. Nganje, M. Linking forest to food security in Africa: Lessons and how to capture forest contributions to semi-urban and and urban food security. Nat. Fauna 2014, 28, 12-16.

19. Clark, K.H. Urban Food Forestry-Low-Hanging Fruit for Improving Urban food Security? Lund University: Lund, Sweden, 2011; Volume 46.

20. Clark, K.H.; Nicholas, K.A. Introducing urban food forestry: A multifunctional approach to increase food security and provide ecosystem services. Landsc. Ecol. 2013, 28, 1649-1669. [CrossRef]

21. Larinde, S.; Oladele, A. Edible Fruit Trees Diversity in a Peri-Urban Centre: Implications for Food Security and Urban Greening. J. Environ. Ecol. 2014, 5, 234-248. [CrossRef]

22. Aworinde, D.O.; Erinoso, S.M.; Ogundairo, B.O.; Olanloye, A.O. Assessment of plants grown and maintained in home gardens in Odeda area Southwestern Nigeria. J. Hortic. For. 2013, 5, 29-36. [CrossRef]

23. Ickowitz, A.; Powell, B.; Salim, M.A.; Sunderland, T.C.H. Dietary quality and tree cover in Africa. Glob. Environ. Chang. 2014, 24, 287-294. [CrossRef]

24. United Nations. World Urbanization Prospects; United Nations: New York, NY, USA, 2014; ISBN 9789211515176.

25. Ghana Statistical Service. 2010 Population and Housing Census Final Results Ghana Statistical Service; Sakoa Press Limited: Accra, Ghana, 2012.

26. Smith, L.; Ruel, M.; Ndiaye, A. Why is Child Malnutrition Lower in Urbanthan in Rural Areas? Evidence from 36 Developing Countries. FCND: Wahington, DC, USA, 2004; Volume 3. 
27. Galbete, C.; Nicolaou, M.; Meeks, K.A.; de-Graft Aikins, A.; Addo, J.; Amoah, S.K.; Smeeth, L.; Owusu-Dabo, E.; Klipstein-Grobusch, K.; Bahendeka, S.; et al. Food consumption, nutrient intake, and dietary patterns in Ghanaian migrants in Europe and their compatriots in Ghana. Food Nutr. Res. 2017, 61, 1341809. [CrossRef] [PubMed]

28. Owusu, J.S.; Colecraft, E.K.; Aryeetey, R.N.; Vaccaro, J.A.; Huffman, F.G. Nutrition Intakes and Nutritional Status of School Age Children in Ghana. J. Food Res. 2017, 6, 11. [CrossRef]

29. Fobil, J.; May, J.; Kraemer, A. Assessing the Relationship between Socioeconomic Conditions and Urban Environmental Quality in Accra, Ghana. Int. J. Environ. Res. Public Health 2010, 7, 125-145. [CrossRef] [PubMed]

30. Stow, D.A.; Weeks, J.R.; Toure, S.; Coulter, L.L.; Lippitt, C.D.; Ashcroft, E. Urban Vegetation Cover and Vegetation Change in Accra, Ghana: Connection to Housing Quality. Prof. Geogr. 2012, 65, 451-465. [CrossRef] [PubMed]

31. Ofori-Sarpong, E.; Annor, J. Rainfall over Accra, 1901-1990. Weather 2001, 56, 55-62. [CrossRef]

32. Simmering, D.; Addai, S.; Geller, G.; Otte, A. A university campus in peri-urban Accra (Ghana) as a haven for dry-forest species. Flora Vegetatio Sudano-Sambesica 2013, 16, 10-21.

33. Creswell, J.W. Steps in Conducting a Scholarly Mixed Methods Study; DBER Speaker Series; Report No.: Paper 48; University of Nebraska: Lincoln, NE, USA, 2013.

34. Hawthorne, W.; Gyakari, N. Photoguide for the Forest Trees of Ghana; Trees Spotters's Field Guide for Identifying the Largest Trees; Oxford Forestry Institute: Oxford, UK, 2006.

35. Oteng-Amoako, A.A. 100 Tropical African Timber Trees from Ghana: Tree Description and Wood Identification with Notes on Distribution, Ecology, Silviculture, Ethnobotany, and Wood Uses; Forest Research Institute of Ghana: Kumasi, Ghana, 2002.

36. Dionisio, K.L.; Arku, R.E.; Hughes, A.F.; Jose Vallarin, O.; Carmichael, H.; Spengler, J.D.; Agyei-Mensah, S.; Ezzati, M. Air Pollution in Accra Neighborhoods: Spatial, Socioeconomic, and Temporal Patterns. Environ. Sci. Technol. 2010, 44, 2270-2276. [CrossRef] [PubMed]

37. Arku, R.E.; Vallarino, J.; Dionisio, K.L.; Willis, R.; Choi, H.; Wilson, J.G.; Hemphill, C.; Agyei-Mensah, S.; Spengler, J.D.; Ezzati, M. Characterizing air pollution in two low-income neighborhoods in Accra, Ghana. Sci. Total Environ. 2008, 402, 217-231. [CrossRef] [PubMed]

38. Heip, C.H.R.; Herman, P.M.J.; Soetaert, K. Indices of diversity and evenness. Oceanis 1998, 24, 61-87.

39. Magurran, A.E. Measuring Biological Diversity; Backwell Publishing: Oxford, UK, 2004.

40. Agbelade, A.D.; Onyekwelu, J.C.; Oyun, M.B. Tree Species Richness, Diversity, and Vegetation Index for Federal Capital Territory, Abuja, Nigeria. Int. J. For. Res. 2017, 2017, 1-12. [CrossRef]

41. Nero, B.F.; Campion, B.B.; Agbo, N.; Callo-Concha, D.; Denich, M. Tree and trait diversity, species coexistence, and diversity- functional relations of green spaces in Kumasi, Ghana. Procedia Eng. 2017, 198, 99-115. [CrossRef]

42. Raoufou, R.; Kouami, K.; Koffi, A. Woody plant species used in urban forestry in West Africa: Case study in Lomé, capital town of Togo. J. Hortic. For. 2011, 3, 21-31.

43. Nero, B.F.; Callo-Concha, D.; Denich, M. Structure, composition and diversity of the tree community of Kumasi, Ghana. Forest 2017, 9, 519. [CrossRef]

44. Kühn, I.; Brandl, R.; Klotz, S. The flora of German cities is naturally species rich. Evol. Ecol. Res. 2004, 6, 749-764. [CrossRef]

45. Mcdonald, R.I.; Marcotullio, P.J.; Guneralp, B. Urbanization, Biodiversity and Ecosystem Services: Challenges and Opportunities. In Urbanization, Biodiversity and Ecosystem Services: Challenges and Opportunities. A Global Assessment; Elmqvist, T., Fragkias, M., Goodness, J., Güneralp, B., Marcotullio, P.J., McDonald, R.I., Parnell, S., Schewenius, M., Sendstad, M., Seto, K.C., et al., Eds.; Springer: Berlin, Germany, 2013; pp. 609-628, ISBN 978-94-007-7087-4.

46. Fuwape, J.A.; Onyekwelu, J.C. Urban Forest Development in West Africa: Benefits and Challenges. J. Biodivers. Ecol. Sci. 2011, 1, 77-94.

47. Eichemberg, M.T.; Christina, M.; Amorozo, D.M.; Moura, C. De Species composition and plant use in old urban homegardens in Rio Claro, Southeast of Brazil. Acta Bot. Bras. 2009, 23, 1057-1075. [CrossRef]

48. Agbogidi, O.M.; Adolor, E.B. Home gardens in the maintenance of biological diversity. Appl. Sci. 2013, 1, $19-25$. 
49. Cilliers, S.; Cilliers, J.; Lubbe, R.; Siebert, S. Ecosystem services of urban green spaces in African countries-Perspectives and challenges. Urban Ecosyst. 2013, 16, 681-702. [CrossRef]

50. Hope, D.; Gries, C.; Zhu, W.; Fagan, W.F.; Redman, C.L.; Grimm, N.B.; Nelson, A.L.; Martin, C.; Kinzig, A.; Nelsonll, A.L. Socioeconomics drive plant diversity. Proc. Natl. Acad. Sci. USA 2003, 100, 8788-8792. [CrossRef] [PubMed]

51. Kinzig, A.P.; Warren, P.S.; Martin, C.; Hope, D.; Katti, M. The effects of human socioeconomic status and cultural characteristics on urban patterns of biodivertsity. Ecol. Soc. 2005, 10. [CrossRef]

52. Food and Agriculture Organization (FAO). Improving Nutrition through Home Gardening; FAO: Rome, Italy, 1996.

53. Danquah, A.O.; Amoah, A.N.; Steiner-Asiedu, M.; Opare-Obisaw, C. Nutritional Status of Participating and Non-participating Pupils in the Ghana School Feeding Programme. J. Food Res. 2012, 1, 263. [CrossRef]

54. Global Panel on Agriculture and Food Systems for Nutrition. Food Systems and Diets: Food Systems and Diets; Global Panel on Agriculture and Food Systems for Nutrition: Accra, Ghana, 2016.

55. Sy, M.; Baguian, H.; Gahi, N. Multiple use of green spaces in Bobo-Dioulasso, Burkina Faso. Urban Agric. Mag. 2014, 27, 33.

56. Elmqvist, T.; Setala, H.; Handel, S.N.; Van Der Ploeg, S.; Aronson, J.; Blignaut, J.N.; Gomez-Baggethun, E.; Nowak, D.J.; Kronenberg, J.; Groot, R. Benefits of restoring ecosystem services in urban areas. Curr. Opin. Environ. Sustain. 2015, 14, 101-108. [CrossRef]

57. Bolund, P.; Hunhammer, S. Ecosystem services in urban areas. Ecol. Econ. 1999, 29, 293-301. [CrossRef]

58. Tzoulas, K.; Korpela, K.; Venn, S.; Yli-Pelkonen, V.; Kaźmierczak, A.; Niemela, J.; James, P. Promoting ecosystem and human health in urban areas using Green Infrastructure: A literature review. Landsc. Urban Plan. 2007, 81, 167-178. [CrossRef]

59. Hosek, L. Urban Forestry in Africa-Insights from a Literature Review on the Benefits and Services of Urban Trees. In Proceedings of the Trees, People and Built Environment II Conference, Edgbaston, UK, 2-3 April 2014; pp. 43-53.

60. Popoola, L.; Ajewole, O. Public perceptions of urban forests in ibadan, nigeria: Implications for environmental conservation. Arboric. J. 2001, 25, 1-22. [CrossRef]

61. Users, F.; Schroeder, H.W. Perceptions and preferences of urban forest users. J. Arboric. 1990, 16, 58-61.

62. Yeboah, A.K. The Interrelationship between Urban Forest and Residential Area Classes-Case Study of the Ayawaso Submetro Districts in the Accra Metropolis, Ghana; University of Eastern Finland: Joensuu, Finland, 2016.

63. Mills, J.R.; Cunningham, P.; Donovan, G.H. Urban forests and social inequality in the Pacific Northwest. Urban For. Urban Green. 2016, 16, 188-196. [CrossRef]

64. Frimpong, J. Planning Regimes in Accra, Ghana. Master's Thesis, University of Waterloo, Waterloo, ON, Canada, 2017.

65. Johnston, M.; Shimada, L.D. Urban forestry in a multicultural society. J. Arboric. 2004, 30, 185-192.

66. Etshekape, P.G.; Atangana, A.R.; Khasa, D.P. Tree planting in urban and peri-urban of Kinshasa: Survey of factors facilitating agroforestry adoption. Urban For. Urban Green. 2018, 30, 12-23. [CrossRef]

67. Faleyimu, O. Public perceptions of Urban forests in Okitipupa Nigeria: Implications for Environmental Conservation. J. Appl. Sci. Environ. Manag. 2014, 18, 469-478.

68. Faleyimu, O.; Akinyemi, M. Socio Economic Assessment of Urban Forestry Respondents' income in Okiti Pupa, Ondo State, Nigeria. J. Appl. Sci. Environ. Manag. 2014, 18, 603-607. [CrossRef]

69. Donovan, G.H.; Mills, J. Environmental justice and factors that influence participation in tree planting programs in Portland, Oregon, U.S. Arboric. Urban For. 2014, 40, 70-77.

(C) 2018 by the authors. Licensee MDPI, Basel, Switzerland. This article is an open access article distributed under the terms and conditions of the Creative Commons Attribution (CC BY) license (http://creativecommons.org/licenses/by/4.0/). 